Western ideas and those of a transdisciplinary character are especially welcome. Book reviews and review articles are also to be published.

The first issue includes, among others, papers by Wande Abimbola on Ifa as a body of knowledge, by Rowland Abiodun on identity and the artistic process in Yoruba aesthetics, by Olufemi Morakinyo on the relevance of indigenous myths to mental health care in West Africa, by Ekong E. Ekong on concepts of metamorphosis in Ibibio society and by A. A. Akiwowo on interpretive sociology in the light of Yoruba religious concepts.

Articles should be sent to the Editor in Chief, Professor A. A. Akiwowo (Department of Sociology/Anthropology, University of Ife) and material for review to the Reviews Editor, Professor Oyin Ogunba (Department of Literature, University of Ife). All inquiries about subscriptions should be addressed to Professor Olufemi Morakinyo (Department of Psychiatry, University of Ife).

\title{
COLLOQUIUM ON AFRICAN RELIGION AND RITUAL
}

The Colloquium on African Religion and Ritual held its first Satterthwaite seminar, convened by Richard Werbner, from 23 to 26 April 1985 at Manchester University's Field Centre in the Lake District. Intended as a small research conference primarily for anthropologists from the United Kingdom, it brought eighteen anthropologists together, including some from the United States, Zimbabwe and Malawi, for sessions on the nature of symbolism, religious change and the state, the logic of ritual and other related themes. It is hoped that the seminar will take place annually. Richard Fardon of St Andrews University is the convenor for 1986 . 